\title{
Administrative Responsibility in Implementing the Program of Secondary Education at the Department of Education in Biak Numfor District
}

\author{
Hamdan \\ Institute of Social and Political Sciences (IISIP), Yapis, Biak \\ Email: unm.hamdan@yahoo.com
}

\section{Doi:10.5901/mjss.2016.v7n3p436}

\begin{abstract}
This study describes the responsibility of the administration and the determinant factors, as well as its implications in implementing secondary education program at education service district of Biak. This research is a qualitative approach to Phenomenology. The data obtained through the techniques of observation, interviews, and documentation. Its analysis technique is an interactive model and drawing conclusions. The results showed that responsibility through the application of the principles of organization of the administration of the managerial, interpersonal, technical, routine and analysis (MITRA) have been implemented in accordance with the standards. Implementations of responsibility on program planning aspects have yet to produce a strategic planning system specific, measureable, attainable, relevant, time-bound (SMART). On the aspect of organizing has been done was the standard implementation of the program. Motivation is the key to the success of the responsibility programs. The factors of leadership and the quality of human resources were also influenced in the process of organizing the administration of secondary education accountability in Biak. The implication that the effectiveness of the responsibility of the administration was the openness of access to education, increasing the number of school age children's participation and the emergence of a sense of Justice for secondary education stakeholders in Biak.
\end{abstract}

Keywords: administration, implementing, program planning, responsibility.

\section{Introduction}

Autonomous region created the real consequences of the autonomous rights of the wider and larger community to prosper in the area, including efforts in optimizing strategy accountability and efficiency of public services at the local level concerning the principle of "local democracy." The demands of regional autonomy in the area of education were based on the perception that during these schools less able to respond to the challenges and needs of a growing community. Therefore, the regional autonomy in the field of education is a right step to give authority and responsibility to local governments in organizing educational services' quality and efficiency to the public, so that the national goal for the intellectual life of the nation could be achieved.

Decentralization provided the impact on the landscape was the democratic system. However, in its use of the intervention of the Central Government to the regions often cannot be only unavoidable, as well as the perspective of the bureaucratic apparatus surveillance is still weak, so the result arose has implications for the fundamental rights of citizens against the still-neglected in the midst of an era of democratization. The concept of responsibility is achieved as a rule and the role of the authority to exercise the power and responsibility. Accountability emerged as public group even individuals to relate to each other and to develop and to maintain the actions of a public company.

In the regency of Biak Numfor, the educational problems of the phenomenon can be seen from the large number of demands and complaints toward education policies implemented by the local government. In administrative accountability dimension, there is a problem. There is inadequate local government capability in addressing the provision of administrative services to the community in an effective manner and responsive. For example, at the admission time, it is still having the burden of costs that must be incurred by parents of students whose son about to proceed to secondary school level. Especially when choosing a school classified as favorite, on the other hand, there is still limited and infrastructure or access to continuing his education.

Strengthening the capacity of the Government through weak accountability becomes progressively worse when faced with the phenomenon of lack of mindset bureaucratic of a government official to serve society as a totality. Paradigm was served and not still inherent in the bureaucratic apparatus work ethic. In addition to the overall human resources, competence is not optimal, either in quality or quantity, as well as support infrastructure not adequate Human resources competency in implementing a responsibility for secondary education in Biak Regency Numfor is still not 
optimal. Government and society lack of synergy in implementing the educational process. This implementation has not been in accordance with the principles of management education that is effective and efficient. Fulfillment of demands of society towards the application of an accountable education process performed by the local authorities, particularly in the department of education, Biak Numfor regency has not performed in accordance with the expectations.

Based on this background, specific research problems can be formulated as follows: How does the Administration's responsibility in implementing the program of secondary education at the Department of Education in Biak Numfor Regency?

\section{Literature Review}

There are several determinant factors that influence responsibility, namely:

\subsection{Organizational Leadership}

Any business must have and need a leader and a top manager to run a leadership action or management for the entire company as a whole.

In order to be a leader able to carry out the functions and role of the complex, a leader is needed for specific terms. A professional leader should have a special requirements, according As'ad (1996) states that the effectiveness of a leader is supported by the existence of the requirements that higher than the average of the subordinates. They are (i) having a high degree of intelligence; (ii) having the ability to speak; (iii) having confidence (iv) having motivated achievers; (v) having ambition.

\subsection{Organizational Culture}

Organizational culture is public consensus about shared values in the life of the Organization and to bind all people within the Organization; organizational culture concerned. It is a public culture of the group will determine what should and not be performed by the members of the Organization, the boundaries of normative behavior of member organizations; the nature and forms of control and oversight of the Organization; managerial style that can be accepted by the members of the Organization; the right way of working, and others.

\subsection{Organizational Climate}

Organizations are primarily a group of people working together to achieve a common goal. The company is a structure that was relied upon by the entire management system to get an efficient business. Therefore, social relationships as the implementing organization has a critical role in social relationships in an organization it can be coloring and give the situation that allows in the group feeling comfortable and at home in their work and pursue a career for the sake of progress and development of the Organization itself.

As for the model frame of this study, the researchers describe a visualization framework through the following research.

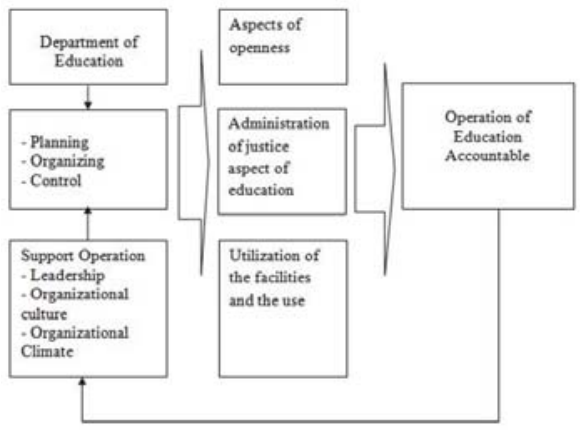

Figure 1. Framework concepts Research 
Accountability as a form of government reports, confirms the view that the government should have standards that emphasize accountability and transparency of public information provision 'sanctions if the future is known to have committed irregularity's accountability. This argument has the hypothesis that the state can be said to be responsible, if capable of representing and realizing a rational public desire in the government's view; the term accountability is only seen as the legality of administrative actions. Public servants and their businesses deemed 'accountable', if they are legally able to explain his actions.

In another view, the idea of responsibility can provide an assessment of the phenomenon or the moral community made parties that have authority to their constituents. This understanding explains the structural position of responsibility. In the domain associated with the emergence of the concept of responsibility governance, oriented form of public interest (public interest).

Classification of responsibility also mapped by Jabra and Dwivedi (1989) which divide the types of responsibility were into five categories. The types are first, administration (organizational) responsibility. Accountability serves as an accountability tool to measure the performance of the government in the public sector. Optimizing the performance of the public sector can be seen from the extent of the implementation of government-run administration. Aspects of the law enforcement interests, culture and other organization were adopted by the public agency. Third political responsibility, accountability focus was on how much impact the political responsibility of the state administration, both executive and legislative to its people.

The delivery of good governance must be controlled in order to create dynamic relationships among actors and elements of government. Fourth, professionally responsibility, this confirms the existence of responsibility of a public organization's actor role in running a business by referring to the effectiveness and efficiency of organizational goals. Fifth, the moral responsibility, this concerns the credibility and accountability of betting organizer's character public companies. The classification of the scope and responsibility at the top were shows that the idea of responsibility as a concept has religious features. The plurality is epistemologies paradigm spawned many methods and multiple interpretations of the meaning. Based on the opinions Keohane and Duke (2002) as cited in Manggaukang (2006) theory of responsibility can also be mapped based on the view of contemporary democracy.

First, accountability hierarchy that shows the features of a large business or bureaucracy and accountability that applies to relationships within the group. Second, accountability, oversight or supervisory responsibility refers to the practice of giving authority to one group to act as principal with regard a particular agent. Third, electoral accountability relating to whether officials will be re-elected or not. Fourth, fiscal accountability mechanisms that explain what the funding agency may require reports from and ultimately sanctions Fifth, which refers to the legal responsibility demands that the agent must comply with formal rules and be prepared to justify their actions in court. Sixth, the marketing responsibility were referred to a particular principal influence on agents, shows partially or entirely through informal markets and delivered through it. Seventh, the participatory responsibility that emerged as a result of the above explanations demands professional performance or actions of bureaucrats. And eighth, accountability reputation.

Stewart Ranson and John Stewart (1994, p. 277) explain the importance of accountability in public administration dimension that: "Public accountability forms a process of public information, of between policy and public discourse. It rates an understanding of information as Reciprocation; of speaking to, but also learning to, the public. However, there is a need, in the analysis, to attend to the condition for public meditation. This can focus of change upon structures and upon power.

\section{Research Method}

The location of the research was on the department of education in Biak Numfor Regency of Papua Province. Location of research was assigned due to the process of implementation of administrative responsibility in implementing the program of secondary education at the education office.

The focus of this research was proceeding in planning educational programs at secondary education service districts of Biak Numfor. The research approach used was the case study. It was an examination of an incident or event and was a research strategy which researchers investigate carefully a program, event, activity or a group of individual processes, phenomena and cases limited by the time and program activities. This research was qualitative research used. This was conducted to analyze in-depth the aspect of the problem of organizing educational programs. The reasons for selecting the approach that this study can explain the actual state or naturalistic in the field qualitatively. Besides, some of factors to influence the accountability of educational at the secondary level can analyze with interview and observation.

Data sources and informants were obtained through: primary Data, it is a data obtained through in-depth interviews 
and methods of observation, through the design of the interview where the researchers directly interact with informants from the bureaucrats and community or education observers. While the process of observation was research on locus of research, that is a function of education in District of Biak Numfor and some high schools, which became the locus of research. Secondary Data were obtained indirectly through an intermediary media (obtained and recorded by others). The data were in the form of evidence, records or historical reports that have been arranged in the archive published and unpublished. Thus, the secondary data were obtained through documents related to policy implementation of secondary education in Biak Numfor.

Informants in this study were the government official bureaucrat that is the head of an educational agency in Districts of Biak Numfor as key informants. The regular informants consist of The Head of Program, the Head of facilities and infrastructure, The head of the field of education and teaching, the Head of sub-division of Finance, headmaster on the level of secondary school, Teachers, supervisor on the level of secondary school, Education practitioners and parents of students.

Data were collected through observation, interview and documentation. The data were validated by using the method of triangulation of the data. Data analysis method used was a descriptive qualitative process by using interactive model entomologist related to the responsibility of the Administration in implementing secondary education in Biak Numfor Regency.

Data analysis steps were performed by reduction of data, Display data, and verification. Conclusion of qualitative researches expected is finding new things based on the results of the study description or representation of an object in order to describe and explain the phenomenon in the form of an interactive relationship in order to get the conclusion.

\section{Results and Discussions}

The process of implementation of the management of secondary education in Biak, it turns out that the implementation process of the implementation stage of education in the working area of District Education Biak Numfor always refers to the area of strategic planning perspective. The institutional unit with other institutional units of mutual interdependence and is unique in implementation. Thus, the aspects related to the educational planning process in relation to responsibility of education itself cannot be separated with the problems formulated plans in each relevant unit.

That in general the program has been prepared essentially been done by the planning system mechanisms and procedures for the preparation of the existing program rules. So although it can be observed that most programs are not formulated to meet the requirements of real, but, in, principle, and a program developed planning mechanism has at least been accommodated by involving the various elements that exist.

The process of planning the implementation of the program of activities of secondary education in Biak directly cannot be managed properly and appropriately if not accompanied and followed by the process of organizing a very important activity. Organizing process in general can be viewed based approach to the placement of human resources held within the structure of the program, the preparation of the basic tasks and functions and duties of each element organizer, as well as the socialization aspect.

Another issue that can be seen by the study of the implementation of the secondary education development programs in Biak was to be assessed based on the view of motivation and guidance. In principle, motivation and management are a variable that indicates the presence and the increased coordination and administration aspects of motivation that will lead members of the company in the process of achieving the goal of developing existing education. Context motivation and management always refer to a system of briefing conducted by members of the organization to other organization members. Achievement targets secondary education development program in Biak can be seen and reached by the role and implications of aspects of motivation and guidance developed by the existing organizational actors. One of the intended targets through the development of the capacity-building program of secondary education is the achievement of learning commitment, the implementation mechanism of the learning process that can be accessed in an organized and increasing community access to existing education.

Based on the description and analysis of research findings can be reconstructed summaries of research findings, thus simplifying this line of thought, as can be seen in the following table. Summary of Research Findings on the Implementation Planning in Secondary Education at the Department of Education in Biak: 
Table 1. Summary of Research Findings on the Implementation Planning in Secondary Education at the Department of Education in Biak

\begin{tabular}{|c|c|c|c|}
\hline Focus Research & Ideal Conditions & Research Findings & Conclusions \\
\hline $\begin{array}{l}\text { Planning in } \\
\text { education at the } \\
\text { District } \\
\text { Education } \\
\text { Office Numfor }\end{array}$ & \begin{tabular}{|l|} 
William Yat Wai Lo \\
$(2008)$ that \\
educational planning \\
is a strategic step in \\
the development of a \\
comprehensive quality
\end{tabular} & $\begin{array}{l}\text { Not rely on participatory planning mechanisms in } \\
\text { the context of the planning strategy, generally } \\
\text { problematic during program execution. The fact is } \\
\text { that there is a plan of the Department of Education, } \\
\text { and the school did not take place according to the } \\
\text { schedule specified time. The absence of synergy in } \\
\text { the preparation of planning control in the } \\
\text { development of education between secondary } \\
\text { education units with the Department of Education. }\end{array}$ & $\begin{array}{l}\text { The dimensions of the implementation } \\
\text { planning educational programs conducted } \\
\text { by the Department of Education provide } \\
\text { meaningful implications and effects on } \\
\text { performance in secondary education unit. } \\
\text { However, the program implementation } \\
\text { plan that has not done well is caused by } \\
\text { the aspect of resource quality. }\end{array}$ \\
\hline
\end{tabular}

Sources: Research Findings (2013)

Analysis of reality based on the design of development planning is used as long as it can be described as visually symmetrical relationships can be formulated as follows:

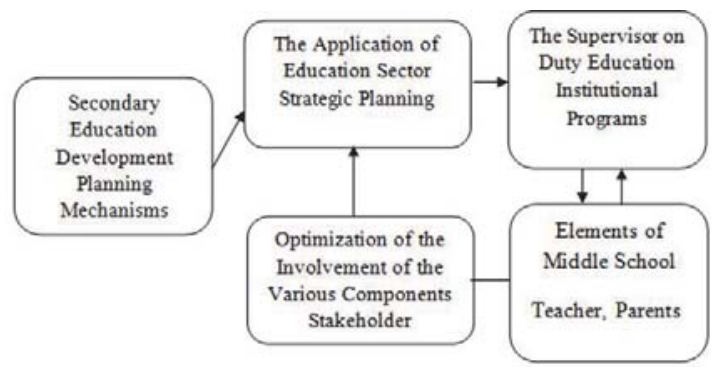

Figure 2. The Planning Framework for Development of Secondary Education

Based on this review can be closed, the context of development planning that argumentative education on secondary education unit in Biak Numfor Regency tends to give effect and meaning to the performance implications of secondary education directly. This can be understood because of the problems of secondary education that is at the core features of the quality of education is directly attributable to the manager for secondary education, especially seen from the perspective of planning program. In other words, the development of secondary education is conducted on the basis of planning on the management strategic basis, including planning strategic process and the involvement of all components of the secondary education. Both in the school and the education service will be able to provide a positive impact on the business of educational responsibility. If analyzed more in depth the characteristics of secondary education development planning process on the implementation of the management strategy or planning strategies and involve communities as elements of education policy, then it can be formulated a proposal with respect to program development planning as follows:

Proposition: the planning program process based education strategies will be able to open a participatory space which in turn generates close to optimal quality management education.

The concept and approach to planning with emphasis on aspects of the approach can trigger the quality of the participation component of secondary education, where through the line like this will be able to give a positive result mainly against the system and mechanism of educational management. In the end as a result of the management education with the system itself can trigger an increase in the quality of the school. The context when associated with the view of organizing the Government as expected by the residents, then the argument further strengthens. The view of Liang Gie in Sjamsiar (2006) that the necessary conditions for the realization of a series of activity management function, including related activities: planning, decision making, supervision, control, and improvement of coordination patterns of works improve the structure and the work of the joint venture in question.

Results of the study indicate that factually conditions the process of implementation of the activities of the secondary education in Biak Numfor Regency has can be implemented based on the programs and activities that have 
been planned in advance. The process of organizing the activities and people as implementers of activities have been organized before implemented on the level and depth of field activities in each school. This has provided some ease of implementation activities of the Organization of the schools, both in the process of teaching and learning or extracurricular which are carried out in accordance with the guidelines and instructions. Although, the subject of the relative quality of learners appears to not given a guarantee optimal success.

The context of organizing the implementation of the development of secondary education by using SOP (Standard Operational Procedure) instruments by education service in Biak Numfor Regency towards the development of middle school high school or vocational school and good in form terms of public and private schools is can be seen from the theory and study Rondinelli (1983) as administrative organizational relationships so that this image can be drawn based on a particular proposal with respect to the implementation of an organizing the development of secondary education as follows:

Proposition 2: Organizing education based on operational guidelines will encourage the effectiveness of institutional relations structuring effective in achieving the purposes of the development of educational programs.

Study of the institutional phenomena by use of approaches standard operational procedures or SOP has been developed since the 1980s, as the study developed by Frederickson (1987) who tries to chart the development of the study of paradigmatic causal agent state administration. Frederickson considers that institutional studies covering functions and operational standards are an important part in the chain of processes and organizations that will provide significant impact in achieving policy objectives organizational bureaucracy. However, the results of the research it had substantial differences with the results of the study undertaken by Riggs (1996) that outstanding complaints on the business and procedural mechanisms are thus based on personality.

Supervision is carried out in implementing secondary education on research results obtained in General can be described that in general secondary education activities at both the high school and vocational school level. Both has guidelines for the supervision of regulated either externally to Department of Education in Biak Numfor Regency as well as the existing supervisory instruments for each existing secondary schools. The communication methods of organizing secondary education on the category of supervision conducted by the Office of education appear to have important implications with respect to the quality of education in Biak Numfor. The dominance of the role of oversight conducted by the Department of Education during the time of organizing secondary education in middle school both high school or vocational school in Biak Numfor Regency provide significant implications to the idea and approach oversight in the view of the theory of public administration. A contextual approach that the model may be released with supervision involves the institutional functions of the Office of education that the majority is more deterministic in the supervisory process in the school allow the occurrence of excessive rigidity at the field level. Riggs (2008) can thus construe these phenomena that the spirit of the enactment of formal rules, including in the exercise of supervisory functions will cause stiffness of the process thus creating in efficiency.

The image can be formulated based on a proposition with respect to the part of the oversight function in the execution and implementation of education as follows:

Proposition 3: Implementations cross-organizational oversight functions - the Department of education of the education service unit (high school/vocational school) and the level of dependency of certain organizations would enhance the process of organizing educational activities.

The implications of these findings are more interesting phenomenon, the existence of both that need to be discussed on the level of theory as well as context. For Riggs (2008) a try initiated indication for efficient use at the time of the use of a rigid procedure including a strict supervision in the process. But the study of these phenomena is more to see Riggs in the organizational context of internal bureaucracy, without connecting it to a more context based cross organizational. But the spirit of regional autonomy which Indonesia put in place including in the process of organizing secondary education have the level of organizational interdependence is high enough. Meanwhile, a study conducted in Biak Numfor is more relevant to Peter O Ilkoyas' study (2008), found the decentralization of education policy to increase the availability of physical facilities and human resource development function at school. Even efficiently manages the infrastructure of the school due to increased administrative responsibility can eliminate the irregularities that occurred in the schools.

\section{Conclusion}

Based on the data analysis and discussion of the research that has been made in the previous section, then it can be formulated some conclusions as follows:

The process of organizing secondary education in working area Department of Education in Biak Numfor Regency 
have not optimized using an approach or perspective strategic plan area, where between an institutional units by other institutional unit mutually interdependence as well as other institutional has its own uniqueness in its execution. So the features related to the educational planning process in relation to the responsibility of education itself cannot be separated with the problems the plan formulated in each unit.

Needed a follow-up of related parties, such as Biak Numfor District Department of Education service can perform a search in order to accurately in the process of formulation development planning program, organizing and monitoring mechanisms. Program based strategic planning with the use it is recommended that can be internalized in the business environment Department of Education up to the level of education in the school unit. Similarly, the institutional setup through organizing is more possible involvement of all stakeholders in the formulation of the plan and its implementation.

On this occasion, the authors convey appreciation and gratitude to the head of Department of Education, the head of the unit Program, the head of the Infrastructure sector, head of sub-division of Financial Education Service Biak Numfor Regency, as well as the principal and teacher Public Senior High School 1 North Biak, principal and teacher Public Senior High School 3 Biak Town, principal and teacher High School/Vocational School Yapis, Supervisor of High School/Vocational School, as well as observers in Biak Numfor Regency.

\section{References}

Abu-Duhou, I. (1999). School Based Management. Fundamental of Educational Planning Series No. 62. Paris. UNESCO - International. Barzely M., \& B. Armajani. (1997). Breaking Through Bureaucracy. New York: Hardcourt Braca.

Chandler, R.C., \& J.C. Piano. (1988). The Public Administration Dictionary. (2nd Ed). Santa Barbara: ABC-CLIO Inc.

Dubnick. (2002). Accountability and ethics: Reconsidering the relationship. International Journal of Organization Theory and Behavior, Autistic Economics Review, 6(3), pp. 405.

Denhardt, V Janet., \& Denhart, B. Robert. (2003). The public Service, Serving Not Sterin. New York: M. L. Sharpe.

Ellwood, J. (2000). Prospect for the study of the Governance of Public Administration. Washington DC: Georgetown University Press.

Fesler, J.W. (1980). Public Administration: Theory and Practice. New Jersey: Prentice-Hall, Inc.

Frederickson, George H. (2002). The Spirit of Public Administration. San Fransisco: Jossey-Bass Publishers.

Frederickson, George H. (2002). The Public Administration Theory Primer. United Kingdom: Westview Press.

Gibson, James L., Ivancevich, John M., \& Donnel, James H. Jr. (1997). Organization and Management. Jakarta: Erlangga.

Jabra. J. G. Dwivedi, O.P. (1989). Public Service Accountability. A Comparative Perspective. USA: Kumarian Press Library.

Kettl, D.F. (1993). Public Administration: The state of the field. In political Science: The State of the discipline II. (Edited by Ada W. Finifler). Washington DC: the America Political Science Association.

Lemay. M. C. (2002). Public Administration: Clashing Values in the Administration of Public Policy. Belmont: Wardsworth/Thompson Learning.

Miles, Matthew B., \& Huberman, A. Michael. (1984). Qualitative Data Analysis: A Sourcebook of New Methods. California: SAGE Publications.

Manggaukang. (2006). Local Government Accountability in the Autonomous Region. Case Study in the Local Government District of Sumbawa NTB Province (Short Journal). Malang: Pasca Sarjana Unibraw Malang.

Manggaukang R. (2006). A New Paradigm of Accountability. Mataram: Government.

Mardiasmo. (2002). Otonomi dan Manajemen Keuangan Daerah. Yogyakarta: Andi Offset.

Mardiasmo. (2004). Series of Autonomous Region "Autonomy and Financial Management Areas". Yogyakarta: Andi Offset.

McCurdy, H. E. (1986). Public Administration: A Bibliographical Guide to the Literature. New York: Marcel Dekker, Inc.

Osborn David., and Gaebler, Ted. (2002). Reinventing Government Bureaucracy, Transform entrepreneurial spirit into the Public Sector. Jakarta: Penerbit PPM.

Osborn David., \& Plastrik, P. (2001). Cut the bureaucracy: the five Strategies towards Entrepreneurial Government. Jakarta: Penerbit PPM.

Government Regulation Number 38 of 2007 Concerning the Government Affairs Division between Government and Local Governance (District/City).

Petters B. Guy. (2001). The Future of Governing. (2nd Ed). Kansas: Kansas University Press.

Rondinelli, Dennis A, et al. (1981). Decentralization in Development Countries: a Review of Recent Experience. Washington DC: World Bank Staff Working Papers.

Robbin, Stephen P. (1994). Organization Theory: Structure, Design and Applications. Jakarta: Penerbit Arcana.

Romzek, B.S., \& Dubinck, J.M. (n.d). Accountability in the Public Sector. Connecticut: Kumarian Press.

Stinette.L.J. (1993). Decentralization: Why, How, and Toward What Ends: NCR Policy Brief. Jakarta: Paramadina dan PT Logos wacana HmuBrief.

Sidi, Indra Djati. (2001). The Learning Society: Conducting Educational Paradigm. Jakarta: Paramadina dan PT Logos Wacana IImu.

Stewart, Ranson., \& Stewart, John. (1994). Management for the public Domain: Enabling the Learning Society. New York: ST. Martins Press.

Schacter, M. (2000). When Accountability Fails: A Framework for Diagnosis and action. Canada: Institute on Governance. 
Shamir, B, et al. (1993). The Motivational Effects of Charismatics Leadership: A Self Concept Based Theory. Organization Science. Smith, B.C. (1985). Decentralization: The Territorial Deletion of the state. Sidney: George Allen \& Urwin.

Stillman II, R.J. (1991). Preface To Public Administration: A Search For Themes And Direction. New York: St.Martins Press.

Wibawa, Fahmi. (2006). Distribution authority of County; A Case Study of the Implementation of Regional Autonomy. Malang: SPOD FE UNIBRAW-PGRI-UNDP-EU.

Utomo, Warsito. (1998). The Role and Strategy of Improvement of Own-Source Revenue in the Implementation of Regional Autonomy. Jurnal IImu Social dan IImu Politik, 1.

Osborn, David., \& Gaebler, Ted. (2002). Reinventing Government Bureaucracy, Transform entrepreneurial spirit into the Public Sector. Jakarta: Penerbit PPM.

Zauhar. (2007). Administrative Reform, Concept, the Dimension and Strategy. Jakarta: PT Bumi Aksara. 